Szymyślik, R. (2021). The Teaching of Literary Translation and the Consistency of Equivalents to obtain Functional Target Narratives: Analysis of the Rendering of Moby Dick by Herman Melville from English into Spanish. Current Trends in Translation Teaching and Learning E, 8, $510-$ 539. https://doi.org/10.51287/cttle202120

\title{
THE TEACHING OF LITERARY TRANSLATION CONSISTENCY EQUIVALENTS FUNCTIONAL AND THE OF TO OBTAIN NARRATIVES: ANALYSIS OF THE RENDERING OF MOBY DICK BY HERMAN MELVILLE FROM ENGLISH INTO SPANISH
}

Robert Szymyślik

Universidad Pablo de Olavide (Seville, Spain)

\section{Abstract}

This paper was developed to draw conclusions about the teaching methods that can be applied to the translation of literary works and about the study of the needs for consistency concerning rendering options in order for students to produce functional target narratives. It was carried out through the analysis of the novel entitled Moby Dick by Herman Melville from English into Spanish from the point of view of transversal narrative coherence. It centres its attention on the multiple translation options that can be employed to transfer specific extracts of this novel (such as 
Szymyślik, R. (2021). The Teaching of Literary Translation and the Consistency of Equivalents to obtain Functional Target Narratives: Analysis of the Rendering of Moby Dick by Herman Melville from English into Spanish. Current Trends in Translation Teaching and Learning E, 8, $510-$ 539. https://doi.org/10.51287/cttle202120

verbs and pronouns whose equivalents must be maintained throughout the complete text) and on showing the importance of a consistent use of these translation options to obtain a functional target text.

Keywords: literary translation, Melville, Moby Dick, narrative consistency, translation teaching

\section{INTRODUCTION AND AIMS}

This paper is centred on the observation of the translation of different sections of Moby Dick by Herman Melville from English into Spanish to teach the importance of an efficient selection of rendering options that are consistent regarding the objectives of the narrative and the information presented by the authors in the classroom. The consistency of equivalents is a basic criterion to assess if a target text exposes the necessary information in order for the target readers (in the case of literary translation) to conceive mentally the alternate world described by each author in a functional way and to enter a translated cosmos that resembles to a great extent the original untranslated universe.

The objective of this paper is to show the potential functional and narrative issues that can occur during the transference of a literary work in a 
Szymyślik, R. (2021). The Teaching of Literary Translation and the Consistency of Equivalents to obtain Functional Target Narratives: Analysis of the Rendering of Moby Dick by Herman Melville from English into Spanish. Current Trends in Translation Teaching and Learning E, 8, $510-$ 539. https://doi.org/10.51287/cttle202120

translation classroom: specifically, the processing of several extracts from Moby Dick by Herman Melville will be studied to assess the significance of the coherent use of translation options and how they could alter the perception of the novel by the target recipients. The multiple functional translation options that can be used to render the pieces of data that contribute to the sense of completeness and cohesion of this literary text will be studied by means of a contrastive analysis of two target texts, the first one translated by Fernando Velasco Garrido and published by Ediciones Akal in 2012 and the second one processed by Enrique Pezzoni and presented by Debolsillo in the same year.

\section{LITERARY TEXTS, LITERARY TRANSLATION AND THE NEED FOR CONSISTENCY REGARDING EQUIVALENTS}

In order to understand literary creation, it is basic to know what a literary text is: Wellek and Warren (1979, pp. 24-26) describe literary texts as any written work that shows aesthetic value or that has been created by means of the artistic virtuosity of its author. Another important notion regarding literary texts (according to these theoreticians) is the fact that a literary work is a composition that 
Szymyślik, R. (2021). The Teaching of Literary Translation and the Consistency of Equivalents to obtain Functional Target Narratives: Analysis of the Rendering of Moby Dick by Herman Melville from English into Spanish. Current Trends in Translation Teaching and Learning E, 8, $510-$ 539. https://doi.org/10.51287/cttle202120

belongs to the spheres of "imaginative fiction" or "fantastic fiction": this means that literary works present alternate universes and the key to enter them is the information found in a narrative (what is linked to the importance of functional and coherent translation procedures to provide readers with a complete target text).

The teaching of translation processes commonly relies on the use of standard and non-specialized texts, especially at early learning stages. The main text typologies that are employed in the classroom are writings related to journalism and tourism, whose complexity is often medium or low and that is why they are suitable for the assimilation of translation strategies (Kelly, 1997). Even audiovisual translation can be helpful to produce the evolution of the interlinguistic abilities shown by the students, although it has characteristics that differ from the conventional translation of texts (Lertola, 2018, pp. 198-199). Literary translation can offer a great number of benefits as well, because, through it, students are able to develop traits such as fluency and a refined style while writing any kind of texts, which might not happen during certain tasks.

During the transference process of this kind of literary structures between languages, diverse ideas 
Szymyślik, R. (2021). The Teaching of Literary Translation and the Consistency of Equivalents to obtain Functional Target Narratives: Analysis of the Rendering of Moby Dick by Herman Melville from English into Spanish. Current Trends in Translation Teaching and Learning E, 8, $510-$ 539. https://doi.org/10.51287/cttle202120

should be taken into account to guarantee that the target recipients will enter a literary universe that resembles to a great extent the one that its author designed originally. First of all, the primal goal of literary translation (as described by Lefevere, 1997, p. 137) should be studied: to enable the reception of a literary work, of an author or of a complete genre in a new sociocultural context, whose members might not be able to access certain works due to linguistic or cultural barriers. Moreover, Bassnett (2002, pp. 110-115) describes that the construction of literary texts relies heavily on stylistic procedures, destined to transmit the content of the plot and, above all, to produce different sensations in the minds of the recipients. The translation strategies applied to the processing of this type of creations should be centred on evoking emotions and not only on the reproduction of the data contained in the original work, in order for the readers to assimilate every layer of a narrative structure (conceptual, textual and emotional) and immerse themselves and enjoy a narrative totally.

Literary translation shows multiple applications apart from the development of expressive and rendering skills in the translation classroom, such as language teaching. Literary translation can reinforce the assimilation of linguistic information 
Szymyślik, R. (2021). The Teaching of Literary Translation and the Consistency of Equivalents to obtain Functional Target Narratives: Analysis of the Rendering of Moby Dick by Herman Melville from English into Spanish. Current Trends in Translation Teaching and Learning E, 8, $510-$ 539. https://doi.org/10.51287/cttle202120

due to the links of this activity to the learning of a new language, which is based initially on a conceptual comparison of notions between the new linguistic code and the one most used by the learners (Szymyślik, 2021, pp. 114-118).

\section{METHODOLOGY}

The method that has been employed to study and show the intricacies of the translation of crucial elements that can contribute to the consistency of the complete narrative contained in Moby Dick is the contrastive analysis of translations, a methodology pertaining to the field of Descriptive Translation Studies and whose main scholars are Lambert and Van Gorp (1985), Van Leuven-Zwart (1989) and Hermans (2014), among others. The notions coming from the works written by these theoreticians were used to develop a specialized procedure that makes the observation of the translation strategies and the functionality of the proposed options regarding the transmission of the content of an original narration possible. The contrastive translation analysis enables researchers to discover particular traits of languages used in specific contexts and the creation of a repertoire of rendering strategies that may solve translation problems that might occur in special communicative situations, such as the transmission 
Szymyślik, R. (2021). The Teaching of Literary Translation and the Consistency of Equivalents to obtain Functional Target Narratives: Analysis of the Rendering of Moby Dick by Herman Melville from English into Spanish. Current Trends in Translation Teaching and Learning E, 8, $510-$ 539. https://doi.org/10.51287/cttle202120

of vital aspects of a narrative between English and Spanish, as will be studied in this paper.

The main notions followed during the completion of this study are the ones defended by the functionalist approach in Translation Studies, mainly the ideas of Bassnett (2002) and Nord (2018): according to Bassnett, the main goal of translators in a literary context is to reproduce the original feelings that a work produced in the recipients in their context of origin (2002, pp. 100115). This idea can be fused with Nord's perspective $(2018$, p. 81 ), who asserted that, in any translation (but especially in the literary field), professionals should pursue the balance between the intended effects and the function of the rendered information, an important issue in an artistic sphere, such as the transmission of the foundations of a narrative and its specific building blocks.

According to Toury (1980, pp. 112-113) and Valero Garcés (2007, p. 129), it is advisable to extract brief samples from the original and the translated works in order to undertake an effective and productive study of the translation strategies employed to transfer a work and to draw conclusions concerning the functionality of each decision. Toury expressed that the length of a 
Szymyślik, R. (2021). The Teaching of Literary Translation and the Consistency of Equivalents to obtain Functional Target Narratives: Analysis of the Rendering of Moby Dick by Herman Melville from English into Spanish. Current Trends in Translation Teaching and Learning E, 8, $510-$ 539. https://doi.org/10.51287/cttle202120

sample is not absolute and that it depends on the specific research, but he stated that the fragment should include the complete solution to a specific translation problem proposed by a translator (2004, p. 122). Furthermore, since Munday (2016, p. 157) asserted that "there is no set model for the analysis of [...] translations", a special system was designed for this paper, following the ideas of Venuti (in Ibid., pp. 155-156), who defended the "analysis of extracts of ST-TT pairs in order to assess the translation strategy prevalent in a given context."

The method followed to explain within the classroom the singularities of the translation of a literary text consisted of the following phases: first of all, several well-known literary texts were selected, which possessed features that could be useful in order to expose how consistency can be maintained from the perspective of the narrative unity of a work and, thus, different strategies and procedures must be implemented to guarantee a functional transference of the information contained by a narrative (as in this case) or in any kind of writing. After this process, it was concluded that the novel Moby Dick by Herman Melville was the most suitable to teach the effects of the selection of certain equivalents on the uniformity of a target text. After a comprehensive selection of samples from the novel, only those 
Szymyślik, R. (2021). The Teaching of Literary Translation and the Consistency of Equivalents to obtain Functional Target Narratives: Analysis of the Rendering of Moby Dick by Herman Melville from English into Spanish. Current Trends in Translation Teaching and Learning E, 8, $510-$ 539. https://doi.org/10.51287/cttle202120

examples that were especially relevant to the requirements of the students and, subsequently, to the specifications of this paper were chosen, taking into account the parameter of its relevance for the maintenance of consistency regarding the whole narration and if they contributed to the complete understanding of the story of Moby Dick. This method was put in practice during the academic year 2017-2018 in the context of different translation courses in the Translation and Interpreting Degree at Universidad Pablo de Olavide (Seville, Spain).

To observe the possible translation issues that can occur during the translation of a literary text to the students in a translation classroom, two translated and published versions of this novel in Spanish (the first one developed by Fernando Velasco Garrido and published by Ediciones Akal and the second one rendered by Enrique Pezzoni and published by Debolsillo) are used to compare the possible translation options that exist to transfer specific pieces of data and how these options can determine the narrative flow of the whole work in its translated versions. The analyzed fragments of the original novel and the target narratives will be contained in specialized cards that will present the surrounding context and the page where they can be found in the original and translated works. The 
Szymyślik, R. (2021). The Teaching of Literary Translation and the Consistency of Equivalents to obtain Functional Target Narratives: Analysis of the Rendering of Moby Dick by Herman Melville from English into Spanish. Current Trends in Translation Teaching and Learning E, 8, $510-$ 539. https://doi.org/10.51287/cttle202120

card model derives from the one used to observe the translation problems linked to fictional worlds developed in Szymyślik (2019, p. 267).

\section{ANALYSIS OF THE TRANSLATION OF EXCERPTS FROM MOBY DICK BY HERMAN MELVILLE FROM ENGLISH INTO SPANISH}

\subsection{The Complete Extract from Moby Dick by Herman Melville used for Translation Training from English into Spanish}

The following section includes the complete original excerpt that was presented to the students to learn the effects of the selection of certain equivalents for key elements of a narrative. The main aim of this didactic exercise was the observation of the influence of these rendering options on the transversal narrative consistency of the whole fragment and, by extension, of the complete novel:

Call me Ishmael. Some years ago-never mind how long precisely-having little or no money in my purse, and nothing particular to interest me on shore, I thought I would sail about a little and see the watery part of the world. It is a way I have of driving off the spleen and regulating the circulation. Whenever I find myself growing grim about the mouth; whenever it is a damp, drizzly November in my soul; whenever I find myself involuntarily pausing before coffin warehouses, and bringing up the rear of every funeral I 
Szymyślik, R. (2021). The Teaching of Literary Translation and the Consistency of Equivalents to obtain Functional Target Narratives: Analysis of the Rendering of Moby Dick by Herman Melville from English into Spanish. Current Trends in Translation Teaching and Learning E, 8, $510-$ 539. https://doi.org/10.51287/cttle202120

meet; and especially whenever my hypos get such an upper hand of me, that it requires a strong moral principle to prevent me from deliberately stepping into the street, and methodically knocking people's hats off- then, I account it high time to get to sea as soon as I can. This is my substitute for pistol and ball. With a philosophical flourish Cato throws himself upon his sword; I quietly take to the ship. There is nothing surprising in this. If they but knew it, almost all men in their degree, some time or other, cherish very nearly the same feelings towards the ocean with me.

There now is your insular city of the Manhattoes, belted round by wharves as Indian isles by coral reefs - commerce surrounds it with her surf. Right and left, the streets take you waterward. Its extreme downtown is the Battery, where that noble mole is washed by waves, and cooled by breezes, which a few hours previous were out of sight of land. Look at the crowds of water-gazers there.

Circumambulate the city of a dreamy Sabbath afternoon. Go from Corlears Hook to Coenties Slip, and from thence, by Whitehall, northward. What do you see? Posted like silent sentinels all around the town, stand thousands upon thousands of mortal men fixed in ocean reveries. Some leaning against the spiles; some seated upon the pier-heads; some looking over the bulwarks of ships from China; some high aloft in the rigging, as if striving to get a still better seaward peep. But these are all landsmen; of week days pent up in lath and plaster - tied to counters, nailed to benches, clinched to desks. How then is this? Are the green fields gone? What do they here?

But look! here come more crowds, pacing straight for the water, and seemingly bound for a dive. Strange! Nothing will content them but the extremest limit of the land; loitering under the shady lee of yonder warehouses will not suffice. No. They must get just as nigh the water as they possibly can without falling in. And there they stand - miles of them-leagues. Inlanders all, they come from lanes and alleys, streets and avenues - north, east, south, and west. Yet here they all unite. Tell me, does the magnetic virtue of the needles of the compasses of all those ships attract them thither? Once more. Say you are in the country; in some high land of lakes. Take almost any path you please, and ten to one it carries you down in a dale, and leaves you there by a pool in the stream. There is magic in it. Let the most absent-minded of men be plunged in his deepest reveries- 
Szymyślik, R. (2021). The Teaching of Literary Translation and the Consistency of Equivalents to obtain Functional Target Narratives: Analysis of the Rendering of Moby Dick by Herman Melville from English into Spanish. Current Trends in Translation Teaching and Learning E, 8, $510-$ 539. https://doi.org/10.51287/cttle202120

stand that man on his legs, set his feet a-going, and he will infallibly lead you to water, if water there be in all that region. Should you ever be athirst in the great American desert, try this experiment, if your caravan happen to be supplied with a metaphysical professor. Yes, as every one knows, meditation and water are wedded for ever. But here is an artist. He desires to paint you the dreamiest, shadiest, quietest, most enchanting bit of romantic landscape in all the valley of the Saco. What is the chief element he employs? There stand his trees, each with a hollow trunk, as if a hermit and a crucifix were within; and here sleeps his meadow, and there sleep his cattle; and up from yonder cottage goes a sleepy smoke. Deep into distant woodlands winds a mazy way, reaching to overlapping spurs of mountains bathed in their hill-side blue. But though the picture lies thus tranced, and though this pine-tree shakes down its sighs like leaves upon this shepherd's head, yet all were vain, unless the shepherd's eye were fixed upon the magic stream before him (Melville, 1892, pp. 7-8).

\subsection{Analysis of the Translation of Key Elements found in Moby Dick by Herman Melville from the Perspective of Narrative Consistency from English into Spanish}

\subsubsection{Description of the Analysis of the Translation of Moby Dick from English into Spanish}

This section comprises the analysis of crucial components of the discourse found in Moby Dick from English into Spanish and their potential for literary translation teaching. As explained before, the examples studied in the classroom are contained in cards which specify the section where 
Szymyślik, R. (2021). The Teaching of Literary Translation and the Consistency of Equivalents to obtain Functional Target Narratives: Analysis of the Rendering of Moby Dick by Herman Melville from English into Spanish. Current Trends in Translation Teaching and Learning E, 8, $510-$ 539. https://doi.org/10.51287/cttle202120

the fragment is located in the novel and the immediate context that surrounds the excerpt. The translated texts that are used to show the variety of options that can be used to translate specific textual fragments are classified as "entries". The section "Translated entry 1" belongs to the target novel translated by Fernando Velasco Garrido and published by Ediciones Akal in 2012 and the section "Translated Entry 2" alludes to the rendered text developed by Enrique Pezzoni and presented by Debolsillo in 2012. The objective of this didactic task was to show the ways in which certain translation options can determine the perception of a complete text and the influence that this factor can have on the understanding and the processing of a production that possesses a great narrative nature and to explain that the cohesion of the equivalents related to one transversal narrative dimension is absolutely crucial to provide the recipients with a functional target literary creation.

\subsubsection{Consistency of the Translation Options regarding Narrative Elements found in Moby Dick by Herman Melville}

This part of the paper is dedicated to the consistency of translation options concerning elements that are linked to the conceptual foundations of this narrative and that can determine 
Szymyślik, R. (2021). The Teaching of Literary Translation and the Consistency of Equivalents to obtain Functional Target Narratives: Analysis of the Rendering of Moby Dick by Herman Melville from English into Spanish. Current Trends in Translation Teaching and Learning E, 8, $510-$ 539. https://doi.org/10.51287/cttle202120

the perspective of the target readers and reinforce or hinder the literary content of this work. The excerpts have been selected taking into account that they are interrelated to specific components of the original discourse and every equivalent used to transfer them must show coherence in order to maintain the sense of unity and the uniformity of the narrative and, thus, enable target recipients to understand the information of this story properly. The studied elements are related to the development of the story: the narrator speaks to an audience (which comprises the readers themselves) and the treatment of the people that are listening to the story (mainly materialized in the use of specific verbs, especially imperatives) must be analyzed and decided by the translators before completing the rendering task and maintained throughout the entire novel. The first example is located in card number 1 :

\begin{tabular}{|l|l|l|}
\hline $\begin{array}{l}\text { Card } \\
\text { number } \\
1\end{array}$ & $\begin{array}{l}\text { Original entry } \\
\text { "Call me Ishmael" }\end{array}$ & $\begin{array}{l}\text { Page of original entry } \\
\text { Context of original entry } \\
\text { "Some years ago-never mind how long precisely-having } \\
\text { little or no money in my purse, and nothing particular to } \\
\text { interest me on shore, I thought I would sail about a little and } \\
\text { see the watery part of the world" }\end{array}$ \\
\hline Translated entry 1 & Page of translated \\
\hline
\end{tabular}


Szymyślik, R. (2021). The Teaching of Literary Translation and the Consistency of Equivalents to obtain Functional Target Narratives: Analysis of the Rendering of Moby Dick by Herman Melville from English into Spanish. Current Trends in Translation Teaching and Learning E, 8, $510-$ 539. https://doi.org/10.51287/cttle202120

\begin{tabular}{|l|l|} 
Llamadme Ismael & $\begin{array}{l}\text { entry } \mathbf{1} \\
25\end{array}$ \\
\hline $\begin{array}{l}\text { Context of translated entry } \mathbf{1} \\
\text { Llamadme Ismael. Hace unos años -no importa exactamente } \\
\text { cuántos-, teniendo poco o ningún dinero en mi bolsa y nada } \\
\text { especial que me interesara en tierra, pensé navegar un poco } \\
\text { y ver la parte acuática del mundo }\end{array}$ \\
$\begin{array}{l}\text { Translated entry } \mathbf{2} \\
\text { Pueden llamarme ustedes Ismael }\end{array}$ & $\begin{array}{l}\text { Page of translated } \mathbf{2} \\
27\end{array}$ \\
\hline $\begin{array}{l}\text { Context of translated entry } \mathbf{2} \\
\text { Pueden llamarme ustedes Ismael. Hace algunos años -no } \\
\text { importa cuántos, exactamente-, con poco o ningún dinero en } \\
\text { mi billetera y nada de particular que me interesara de esta } \\
\text { tierra, pensé en darme a la mar y ver la parte líquida del } \\
\text { mundo }\end{array}$ \\
\hline
\end{tabular}

This is the core excerpt whose translation has influence over the next segments of the novel, even the whole of it. The first three words of this work ("Call me Ishmael") have an outstanding effect on the equivalents that could be used in the following examples that are related to the treatment of the audience of this novel. Particularly, this transversal translation issue is linked to the translation of verbs between English and Spanish: there is no formal distinction between the second person singular and the second person plural in English (but in Spanish there is a distinction between them) and, in this text, several examples appear that could cause 
Szymyślik, R. (2021). The Teaching of Literary Translation and the Consistency of Equivalents to obtain Functional Target Narratives: Analysis of the Rendering of Moby Dick by Herman Melville from English into Spanish. Current Trends in Translation Teaching and Learning E, 8, $510-$ 539. https://doi.org/10.51287/cttle202120

interferences during translation, such as the ones contained in the cards presented afterwards. The option used by each translator to transfer the fragment "Call me Ishmael" (which includes an imperative) determines a great number of subsequent equivalents that can be used to render different verbs in any tense, pronouns and even complete sentences, many of them unsuitable due to the necessity for consistency throughout the whole narrative. Without more context and if the professional must undertake the translation of this fragment without more information, there are several functional options (a sign of the wide translatability of this section, that is, the existence of multiple functional options for one linguistic element) to transmit this imperative to the readers, such as, for example:

1. Llámame (second person singular, informal register).

2. Llamadme (second person plural, informal register).

3. Llámeme (second person singular, formal register).

4. Llámenme (second person plural, formal register).

5. Puedes llamarme (second person singular, informal register). 
Szymyślik, R. (2021). The Teaching of Literary Translation and the Consistency of Equivalents to obtain Functional Target Narratives: Analysis of the Rendering of Moby Dick by Herman Melville from English into Spanish. Current Trends in Translation Teaching and Learning E, 8, $510-$ 539. https://doi.org/10.51287/cttle202120

6. Podéis llamarme (second person plural, informal register).

7. Puede llamarme (second person singular, formal register).

8. Pueden llamarme (second person plural, formal register).

All of them could be functional depending on the context and the number of people immersed in the conversation that takes place in this section of the novel. This is why the translator could use any one of them, but they should use the same option throughout the section that is affected by this element, or even the whole narrative to preserve the syntactical consistency and the sense of unity that the novel needs to present its data to the readers. The context of the narrative specifies that the narrator is speaking to an audience, which could be formed by one or by more than one person (that is, the readers of this work conceived collectively) and this fact limits the available equivalents to translate this section. Both translators concluded that the audience includes several people and they used plural forms of this imperative. However, in "Translated entry 1", it can be seen that the translator inserted this element into an informal register, while in "Translated entry 2" a formal register can be detected. Both equivalents are functional, but they establish a 
Szymyślik, R. (2021). The Teaching of Literary Translation and the Consistency of Equivalents to obtain Functional Target Narratives: Analysis of the Rendering of Moby Dick by Herman Melville from English into Spanish. Current Trends in Translation Teaching and Learning E, 8, $510-$ 539. https://doi.org/10.51287/cttle202120

conceptual differentiation regarding the discourse and the attitude of the narrator towards the audience. Nevertheless, the text can be perfectly understood in both cases.

The possible distance between different segments within the same text that are linked to each other from a linguistic, narrative and conceptual point of view could lead translators to lose the sense of completeness of the narrative and the perspective of the options used in previous segments and cause that the equivalents used by students and even professionals not to be consistent with the ones that they chose in previous sections of a narrative. The target recipients, in this case, could not interpret properly the story and have problems to understand the events described by Melville in his novel because the equivalents would provide them with contradictory information. The necessity for consistency does not disappear, because the question of number and register concerning diverse verbs and pronouns is permanently present in this text and conditions the correct comprehension of the story by the target recipients and several additional examples can be located in the following excerpts (compiled in card number 2) in which the use of global functional equivalents is needed: 
Szymyślik, R. (2021). The Teaching of Literary Translation and the Consistency of Equivalents to obtain Functional Target Narratives: Analysis of the Rendering of Moby Dick by Herman Melville from English into Spanish. Current Trends in Translation Teaching and Learning E, 8, $510-$ 539. https://doi.org/10.51287/cttle202120

\begin{tabular}{|c|c|c|}
\hline $\begin{array}{l}\text { Card } \\
\text { lumber }\end{array}$ & see?" & Pag \\
\hline \multicolumn{3}{|c|}{$\begin{array}{l}\text { Context of original entry } \\
\text { "Circumambulate the city of a dreamy Sabbath afternoon. Go } \\
\text { from Corlears Hook to Coenties Slip, and from thence, by } \\
\text { Whitehall, northward. What do you see? Posted like silent } \\
\text { sentinels all around the town, stand thousands upon thousands } \\
\text { of mortal men fixed in ocean reveries" }\end{array}$} \\
\hline \multicolumn{2}{|c|}{$\begin{array}{l}\text { Translated entry } 1 \\
\text { ¿Qué es lo que veis? }\end{array}$} & $\begin{array}{l}\text { Pages of translated } \\
\text { entry } 1 \\
25-26\end{array}$ \\
\hline \multicolumn{3}{|c|}{$\begin{array}{l}\text { Context of translated entry } 1 \\
\text { Rodead la ciudad en una somnolienta tarde del día del Señor } \\
\text { Id desde Corlears Hook a Coenties Slip, y desde allí, por } \\
\text { Whitehall, hacia el norte. ¿Qué es lo que veis?... Apostados } \\
\text { como silenciosos centinelas a todo alrededor de la urbe, hay } \\
\text { miles y miles de mortales absortos en oceánicas ensoñaciones }\end{array}$} \\
\hline \multicolumn{2}{|c|}{$\begin{array}{l}\text { Translated entry } 2 \\
\text { ¿Qué ven ustedes? }\end{array}$} & \begin{tabular}{|l} 
Page of translated \\
entry 2 \\
27
\end{tabular} \\
\hline \multicolumn{3}{|c|}{$\begin{array}{l}\text { Context of translated entry } 2 \\
\text { Recorran ustedes la ciudad en la tarde soñolienta de un } \\
\text { sábado. Vayan desde Corlears Jock hasta Coenties Slip y } \\
\text { desde allí, pasando por Whitehall, hacia el norte. ¿Qué ven } \\
\text { ustedes? Apostados como centinelas silenciosos en torno a la } \\
\text { ciudad toda, hay millares y millares de mortales perdidos en } \\
\text { divagaciones oceánicas }\end{array}$} \\
\hline
\end{tabular}

As explained before, the option used by the student or the translator to render the first fragment of the 
Szymyślik, R. (2021). The Teaching of Literary Translation and the Consistency of Equivalents to obtain Functional Target Narratives: Analysis of the Rendering of Moby Dick by Herman Melville from English into Spanish. Current Trends in Translation Teaching and Learning E, 8, $510-$ 539. https://doi.org/10.51287/cttle202120

novel will determine the register and the number of recipients of the discourse of the narrator and, thus, the perception of the target recipients of the whole story. Any interference in the translation of any component of this narrative related to this initial element could cause difficulties to understand some passages or even produce a distortion of the global vision of Moby Dick or any literary text that includes elements such as this one, issues that are treated differently in each language. In this case, the translators of each text have maintained their preferences regarding the people involved in the discourse of the narrator and the register of the equivalent used in the first sentence of the novel: in the "Translated entry 1", the plural form of the verb "do" and the informal manifestation of this verb in Spanish can be seen (¿Qué es lo que veis?), while in the "Translated entry 2 " the formal sentence ¿Qué ven ustedes? can be detected. This means that the translators have respected their own decisions regarding the treatment of the audience in this paragraph, what makes that the reception of the data of the novel is functionally performed by the readers. Other examples can be found in the following excerpts, gathered together in card number 3: 
Szymyślik, R. (2021). The Teaching of Literary Translation and the Consistency of Equivalents to obtain Functional Target Narratives: Analysis of the Rendering of Moby Dick by Herman Melville from English into Spanish. Current Trends in Translation Teaching and Learning E, 8, $510-$ 539. https://doi.org/10.51287/cttle202120

\begin{tabular}{|c|c|c|}
\hline $\begin{array}{l}\text { ard } \\
\text { Imber }\end{array}$ & . & 1 \\
\hline \multicolumn{3}{|c|}{$\begin{array}{l}\text { Context of original entry } \\
\text { "But look! here come more crowds, pacing straight for } \\
\text { thewater, and seemingly bound for a dive. Strange! Nothing } \\
\text { will content them but the extremest limit of the land; loitering } \\
\text { under the shady lee of yonder warehouses will not suffice" }\end{array}$} \\
\hline \multicolumn{2}{|c|}{$\begin{array}{l}\text { Translated entry } 1 \\
\text { ¡Pero observad! }\end{array}$} & $\begin{array}{l}\text { age of tra } \\
\text { ntry } 1 \\
6\end{array}$ \\
\hline \multicolumn{3}{|c|}{$\begin{array}{l}\text { Context of translated entry } 1 \\
\text { ¡Pero observad! Aquí vienen más gentes, andando derecha } \\
\text { hacia el agua, y aparentemente dispuestas a una zambullida } \\
\text { ¡Es extraño! Con nada se conformarán que no sea el límite } \\
\text { último de la tierra; no será suficiente con pasear a } \\
\text { sombreado socaire de aquellos almacenes }\end{array}$} \\
\hline \multicolumn{2}{|c|}{$\begin{array}{l}\text { Translated entry } 2 \\
\text { Pero imiren ustedes! }\end{array}$} & age of translated \\
\hline \multicolumn{3}{|c|}{$\begin{array}{l}\text { Context of translated entry } 2 \\
\text { Pero imiren ustedes! Llega aun más gente. Todos avanzar } \\
\text { hacia el agua y parecen resueltos a zambullirse. iQue } \\
\text { extraño! Nada los contentaría tanto como el límite extremo de } \\
\text { la tierra; no les basta vagabundear a la sombra de lo } \\
\text { depósitos que rodean el puerto }\end{array}$} \\
\hline
\end{tabular}

The fragment "But look!" is also an imperative that refers to the participants involved in the discourse of the narrator and is affected by the equivalents selected previously by the translators: in order to 
Szymyślik, R. (2021). The Teaching of Literary Translation and the Consistency of Equivalents to obtain Functional Target Narratives: Analysis of the Rendering of Moby Dick by Herman Melville from English into Spanish. Current Trends in Translation Teaching and Learning E, 8, $510-$ 539. https://doi.org/10.51287/cttle202120

maintain a high degree of consistency in the whole text, the same references towards the number of people that the narrator is exposing his tale to and the level of formality applied to this conversation must be reproduced in this case. As can be detected in the translated fragments of the novel incorporated to this card, the professionals used the same parameters to allude to the audience of the narrator, that is: in the first case, Velasco used the plural and informal form Observad (as shown in "Translated entry 1") and Pezzoni employed the plural and formal form Pero imiren ustedes!, which is coherent with their initial decisions concerning the translation of the novel. The final segment of card number 4 incorporates several examples that are also relevant to study the consistency of the translation options:

\begin{tabular}{|l|l|l|}
\hline $\begin{array}{l}\text { Card } \\
\text { number }\end{array}$ & $\begin{array}{l}\text { Original entries } \\
\text { "Say you are in the country } \\
{[\ldots] . \text { Take almost any path you }} \\
\text { please, }[\ldots] \text { it carries you }[\ldots] \\
\text { and leaves you }[\ldots] . \text { Let the } \\
\text { most absent-mided of men } \\
{[\ldots] "}\end{array}$ & $\begin{array}{l}\text { Page of original } \\
\text { entries }\end{array}$ \\
\\
$\begin{array}{l}\text { Context of original entries } \\
\text { "Once more. Say you are in the country; in some high land of } \\
\text { lakes. Take almost any path you please, and ten to one it } \\
\text { carries you down in a dale, and leaves you there by a pool in } \\
\text { the stream. There is magic in it. Let the most absent-minded }\end{array}$
\end{tabular}


Szymyślik, R. (2021). The Teaching of Literary Translation and the Consistency of Equivalents to obtain Functional Target Narratives: Analysis of the Rendering of Moby Dick by Herman Melville from English into Spanish. Current Trends in Translation Teaching and Learning E, 8, $510-$ 539. https://doi.org/10.51287/cttle202120

\begin{tabular}{|c|c|}
\hline \multicolumn{2}{|l|}{ of men be plunged in his deepest reveries" } \\
\hline $\begin{array}{l}\text { Translated entries } 1 \\
\text { Digamos que estáis en el campo [...]. } \\
\text { Tomad casi cualquier camino que deseéis, } \\
\text { [...] que os conduce [...] y que alli os } \\
\text { deja [...]. Dejad que el más despistado de } \\
\text { los hombres [...] }\end{array}$ & \begin{tabular}{|l|} 
Page \\
translated \\
entries 1 \\
26
\end{tabular} \\
\hline \multicolumn{2}{|c|}{$\begin{array}{l}\text { Context of translated entries } 1 \\
\text { Una vez más. Digamos que estáis en el campo, en unas altas } \\
\text { tierras de lagos. Tomad casi cualquier camino que deseéis, y } \\
\text { apuesto diez contra uno que os conduce a un valle y que allì } \\
\text { os deja junto a un remanso de la corriente. Hay magia en } \\
\text { ello. Dejad que el más despistado de los hombres se sumerja } \\
\text { en sus más profundas ensoñaciones... }\end{array}$} \\
\hline $\begin{array}{l}\text { Translated entries } 2 \\
\text { Supongamos que se encuentren [...]. } \\
\text { Tomen cualquier sendero que se les } \\
\text { antoje: [...] irán a dar [...]. Elijamos al } \\
\text { más distraído de los hombres [...] }\end{array}$ & \begin{tabular}{|l|} 
Page \\
translated \\
entries 2 \\
28
\end{tabular} \\
\hline \multicolumn{2}{|c|}{$\begin{array}{l}\text { Context of translated entries } 2 \\
\text { Y eso no es todo. Supongamos que se encuentren ustedes en } \\
\text { un paraje elevado, donde abunden los lagos. Tomen } \\
\text { cualquier sendero que se les antoje: casi siempre irán a dar, } \\
\text { a través de un valle, a un estanque formado por la corriente. } \\
\text { Hay en ello algo mágico. Elijamos al más distraído de los } \\
\text { hombres sumergido en su más honda ensoñación [...] }\end{array}$} \\
\hline
\end{tabular}

In this fragment, different verbs can be seen: "say", "take", "please" and "let" and several pronouns that are affected by the needs for consistency expressed above ("you", which is used twice). The 
Szymyślik, R. (2021). The Teaching of Literary Translation and the Consistency of Equivalents to obtain Functional Target Narratives: Analysis of the Rendering of Moby Dick by Herman Melville from English into Spanish. Current Trends in Translation Teaching and Learning E, 8, $510-$ 539. https://doi.org/10.51287/cttle202120

chosen register and the perception of an individual or multiple audience determine the functional options that can be employed to transfer these textual elements (as in the previous cases). As it could be seen in the previous examples, Velasco chose to use an informal register and the plural forms of the verbs and Pezzoni opted for a formal style and also for plural forms of the verbs exposed by Melville. These decisions not only have an influence on verbs, but also on adverbs, as can be seen in this example. The register and the number of people that the audience of the novel comprises must be coherent to transfer a univocal message to the recipients without contradictions, which may diminish the functionality of the whole text and damage the assimilation of the data of this work. The verbs of this passage maintain the nature of the previous options and transfer the next part of Melville's message properly and the pronouns are rendered following the previous decisions and it can be seen that the pronoun "you" is transferred in Velasco's version as os (which indicates an informal register) and, in the case of the translation developed by Pezzoni, the equivalent les can be detected, which refers to a formal register. These equivalents show that both translators have perpetuated their initial perspective of the novel through the whole studied excerpt. 
Szymyślik, R. (2021). The Teaching of Literary Translation and the Consistency of Equivalents to obtain Functional Target Narratives: Analysis of the Rendering of Moby Dick by Herman Melville from English into Spanish. Current Trends in Translation Teaching and Learning E, 8, $510-$ 539. https://doi.org/10.51287/cttle202120

\section{CONCLUSIONS}

This paper has shown the importance of teaching how the options chosen by professionals at early stages of a translation task (not only in the field of literary translation) can determine the available equivalents in a great number of different sections within the same texts. Moreover, it has exposed that students must be aware of the fact that consistency regarding equivalents (from the perspective of terminology or style, among other spheres) is essential to produce functional target texts that present unity and uniformity to the readers.

Thanks to the teaching approach shown in this paper and applied in the classroom during the academic year 2017-2018, translation students have discovered the ramifying influence that a single decision regarding a particular element of a discourse can have over the whole information transfer process between languages in the context of a specific rendering assignment, a fact that was previously unknown to them. In this way, students learn to pay heed to every detail and to conceive a discourse as a polimorphous and interconnected entity in which every strategy can determine the functionality of the complete discourse and to be aware of the differences between English and 
Szymyślik, R. (2021). The Teaching of Literary Translation and the Consistency of Equivalents to obtain Functional Target Narratives: Analysis of the Rendering of Moby Dick by Herman Melville from English into Spanish. Current Trends in Translation Teaching and Learning E, 8, $510-$ 539. https://doi.org/10.51287/cttle202120

Spanish (in this concrete case) in terms of the expression of certain concepts and the possible procedures that can be put into practice to show linguistic data to new recipients.

Not maintaining the same rendering options could cause understanding distortions related to the target recipients and, thus, hinder the evocation and the assimilation of the data designed by Melville (or any other author) and the feelings and the literary joy that a narrative like this one should cause will not be experienced by the readers in the target language. The translators of the analyzed target texts (Velasco and Pezzoni) interpreted the text and decided to use certain options and they perpetuated them consistently throughout the narrative, what is an absolutely functional procedure that enables readers to perceive Melville's creation without any kind of disturbance.

During the teaching of literary translation (and any other modality, because each one of them depends on the needs for coherence), it is basic for the students to understand that they will manipulate works of art and that these productions must possess a unique voice to comprehend functionally all aspects that their authors incorporated to them in terms of story, style and the concrete information 
Szymyślik, R. (2021). The Teaching of Literary Translation and the Consistency of Equivalents to obtain Functional Target Narratives: Analysis of the Rendering of Moby Dick by Herman Melville from English into Spanish. Current Trends in Translation Teaching and Learning E, 8, $510-$ 539. https://doi.org/10.51287/cttle202120

that makes the perception of the alternate reality designed by each writer possible.

This paper shows that Moby Dick by Herman Melville is a suitable option to undertake an analysis destined to the teaching of the importance of consistency to produce a functional literary text, a notion that can be applied to any kind of translation modality to improve the skills of translation and interpreting students. The development of a coherent target novel, for instance, is a demanding task in which a great number of factors can have an essential influence on the reception of a narrative and students can understand this fact by means of studies like the one exposed in this paper, because the results provided by this analysis can offer valuable data in order to understand the complexities of literary translation in the classroom. 
Szymyślik, R. (2021). The Teaching of Literary Translation and the Consistency of Equivalents to obtain Functional Target Narratives: Analysis of the Rendering of Moby Dick by Herman Melville from English into Spanish. Current Trends in Translation Teaching and Learning E, 8, $510-$ 539. https://doi.org/10.51287/cttle202120

\section{REFERENCES}

Bassnett, S. (2002). Translation Studies. Routledge.

Hermans, T. (2014). Translation in Systems: Descriptive and System-Oriented Approaches Explained. Routledge.

Kelly, D. (1997). La enseñanza de la traducción inversa de textos 'generales': consideraciones metodológicas. In M. A. Vega \& R. Martín-Gaitero (Eds.), La palabra vertida. Investigaciones en torno a la traducción (pp. 175-181). IULMT/UCM.

Lambert, J. \& Van Gorp, H. (1985). On Describing Translations. In T. Hermans (Ed.), The Manipulation of Literature. Studies in Literary Translation (pp. 42-53). Croom Helm.

Lefevere, A. (1997). Traducción, reescritura y la manipulación del canon literario (C. Á. Vidal \& R. Álvarez, Trans.). Colegio de España. (Original work published 1992). 
Szymyślik, R. (2021). The Teaching of Literary Translation and the Consistency of Equivalents to obtain Functional Target Narratives: Analysis of the Rendering of Moby Dick by Herman Melville from English into Spanish. Current Trends in Translation Teaching and Learning E, 8, $510-$ 539. https://doi.org/10.51287/cttle202120

Lertola, J. (2018). From Translation to Audiovisual Translation in Foreign Language Learning. TRANS, 22, 185-202.

Melville, H. (1892). Moby Dick or The White Whale. The St. Botolph Society.

Melville, H. (2012a). Moby Dick o La Ballena (F. Velasco Garrido, Trans.). Akal. (Original work published 1851).

Melville, H. (2012b). Moby Dick o la ballena blanca (E. Pezzoni, Trans.). Debolsillo. (Original work published 1851).

Munday, J. (2016). Introducing Translation Studies. Theories and Applications. Routledge.

Nord, C. (2018). Translating as a Purposeful Activity: Functionalist Approaches Explained. Routledge.

Szymyślik, R. P. (2019). Estudio de los problemas de traducción vinculados a mundos ficticios: Fahrenheit 451 de Ray Bradbury [Doctoral Dissertation, Universidad Pablo de Olavide, Seville]. 
Szymyślik, R. (2021). The Teaching of Literary Translation and the Consistency of Equivalents to obtain Functional Target Narratives: Analysis of the Rendering of Moby Dick by Herman Melville from English into Spanish. Current Trends in Translation Teaching and Learning E, 8, $510-$ 539. https://doi.org/10.51287/cttle202120

Szymyślik, R. (2021). The Practice of Literary Translation and Language Teaching in Integration Environments. FITISPos International Journal, 8 (1), 110-121.

Toury, G. (1980). In Search of a Theory of Translation. Porter Institute for Poetics.

Toury, G. (2004). Los estudios descriptivos de traducción y más allá. Metodología de la Investigación en Estudios de Traducción (R. Merino Álvarez \& R. Rabadán, Trans.). Cátedra. (Original work published 1995).

Valero Garcés, C. (2007). Modelo de evaluación de obras literarias traducidas. Peter Lang.

Van Leuven-Zwart, K. M. (1989). Translation and Original: Similarities and Dissimilarities. John Benjamins Publishing Company. 